\title{
Quantitative relationship of two viruses (MrNV and XSV) in white-tail disease of Macrobrachium rosenbergii
}

\author{
Huajun Zhang ${ }^{1}$, Jianmin Wang ${ }^{1}$, Junfa Yuan ${ }^{1}$, Lijuan Li $^{1}$, Jianhong Zhang ${ }^{1}$, \\ Jean-Robert Bonami ${ }^{2}$, Zhengli Shi ${ }^{1, *}$
}

${ }^{1}$ State Key Laboratory of Virology, Wuhan Institute of Virology, Chinese Academy of Sciences, 430071 Wuhan, China ${ }^{2}$ Pathogens and Immunity, UMR5119, ECOLAG, CNRS/UM2, Université Montpellier 2, Montpellier, France

\begin{abstract}
Macrobrachium rosenbergii nodavirus (MrNV) and extra small virus (XSV) were purified from diseased freshwater prawns M. rosenbergii and used to infect healthy post-larvae (PL) by an immersion method. Three groups of prawns were challenged with various combined doses of MrNV and XSV. Signs of white-tail disease (WTD) were observed in Groups 1 and 2, which had been challenged with combinations containing relatively high proportions of $M r N V$ and low proportions of XSV. By contrast there was little sign of WTD in Group 3, which had been challenged with a higher proportion of XSV than MrNV. A 2-step Taqman real-time RT-PCR was developed and applied to quantify viral copy numbers in each challenged PL. Results showed that genomic copies of both viruses were much higher in Groups 1 and 2 than they were in Group 3, indicating that $M r N V$ plays a key role in WTD of $M$. rosenbergii. The linear correlation between MrNV and XSV genome copies in infected prawns demonstrated that XSV is a satellite virus, dependent on $M r N V$, but its role in pathogenicity of WTD remains unclear.
\end{abstract}

KEY WORDS: Macrobrachium rosenbergii · Nodavirus · Extra small virus · Real-time RT-PCR · White-tail disease

Resale or republication not permitted without written consent of the publishe

\section{INTRODUCTION}

The giant freshwater prawn Macrobrachium rosenbergii de Man is one of the most economically important crustaceans in freshwater aquaculture in China, but it is also cultured widely in areas of the Caribbean and in other Asian countries. Since 1990, white-tail disease (WTD) has been prevalent in the main culture areas such as Thailand, Guadeloupe, the Antilles, China and India (Nash et al. 1987, Anderson et al. 1990, Arcier et al. 1999, Tung et al. 1999, Qian et al. 2002, Sahul Hameed et al. 2004). Two kinds of viral particles have been isolated from WTD prawns; one is a nodavirus ( $M$. rosenbergii nodavirus or $M r N V$ ) and the other a smaller virus associated with MrNV (called extra small virus or XSV) (Qian et al. 2003, Shi et al.
2004). Both viruses have been well characterized. MrNV is 26 to $27 \mathrm{~nm}$ in diameter, icosahedral and nonenveloped with a genome consisting of 2 linear ssRNA fragments ( 3 and $1.2 \mathrm{~kb}$ ). XSV is $15 \mathrm{~nm}$ in diameter, icosahedral and non-enveloped, and possesses a linear ssRNA genome of $0.9 \mathrm{~kb}$ encoding 2 overlapping structural proteins of 16 and $17 \mathrm{kDa}$ (Shi et al. 2004, Sri Widada \& Bonami 2004, Bonami et al. 2005).

Various methods have been developed to detect $\mathrm{MrNV}$ and XSV. A sandwich enzyme-linked immunosorbent assay (S-ELISA) and 3 complementary genome-based methods, i.e. dot-blot hybridization, in situ hybridization and reverse transcriptasepolymerase chain reaction (RT-PCR), are available for the detection of $\mathrm{MrNV}$ (Romestand \& Bonami 2003, Sri Widada et al. 2003). Dot-blot hybridization 
and RT-PCR were also developed to detect XSV (Sri Widada et al. 2004). More recently, Yoganandhan et al. (2005) established a 1-step multiplex RT-PCR to detect MrNV and XSV simultaneously. These methods have facilitated the diagnosis of WTD.

Due to the small size and absence of an RNA-dependent RNA polymerase (RdRp) gene in the XSV genome, it was believed that XSV is a satellite virus (Sri Widada \& Bonami 2004). In our previous studies, $\mathrm{MrNV}$ and XSV were always found co-located in the connective tissues of diseased prawns (Qian et al. 2003, Shi et al. 2004). Experimental infection with a mixture of the 2 viruses demonstrated that WTD in Macrobrachium rosenbergii could be attributed to one or both of them. Without purification and separation of $\mathrm{MrNV}$ and XSV, the role and relationship of these 2 viruses in WTD of $M$. rosenbergii remains uncertain.

In this study, MrNV and XSV were purified and separated from diseased Macrobrachium rosenbergii and used to infect healthy post-larvae (PL). Real-time RTPCR was developed and used to quantify copy numbers of the 2 viruses in challenged PL and investigate their role and relationship in WTD.

\section{MATERIALS AND METHODS}

Post-larvae. Five-d-old healthy Macrobrachium rosenbergii PL, with no history of WTD, were purchased from a hatchery in Wuhan (Hubei Province, China). The PL were reared in $50 \times 38 \times 23 \mathrm{~cm}$ disinfected tanks and fed powdered eggs 3 times a day. Excreta and food remains were removed daily. Water temperature was controlled at 25 to $27^{\circ} \mathrm{C}$, and the tanks were gently aerated. Two-thirds of the freshwater was exchanged each day.

MrNV and XSV purification. Infected PL were collected from a hatchery in Zhejiang Province (China) and stored at $-70^{\circ} \mathrm{C}$. Purification was performed as described previously (Bonami et al. 2005). Briefly, the PL were homogenized in PBS buffer $(\mathrm{pH}$ 7.4) and clarified at $10000 \times g$ for $25 \mathrm{~min}$. The resultant supernatant was centrifuged at $160000 \times g$ for $4 \mathrm{~h}$ at $4^{\circ} \mathrm{C}$. The pellets were resuspended in PBS, followed by extraction 2 to 3 times with Freon (1,1,2-trichloro$2,2,1$ trifluoroethane). Then, the aqueous layer was centrifuged at $160000 \times g$ for $4 \mathrm{~h}$. The 2 viruses were separated with a 15 to $30 \%$ (w/v in PBS) sucrose gradient, followed by a $\mathrm{CsCl}$ gradient. The viruses were quantified by real-time RT-PCR as indicated below. The purified virions were stored at $-70^{\circ} \mathrm{C}$.

Experimental infections. The 5-d-old PL were reared for $3 \mathrm{~d}$ and starved for $1 \mathrm{~d}$ before challenge. RTPCR with $M r N V$ - and XSV-specific primers was performed to confirm the health of the PL. Three groups of healthy PL were challenged with different combinations of the 2 purified viruses-Group 1: $3.49 \times 10^{13}$ $M r N V$ and $9.82 \times 10^{11} \mathrm{XSV} \mathrm{ml}^{-1}$ (i.e. $\mathrm{MrNV}: \mathrm{XSV}=$ 36:1); Group 2: $1.75 \times 10^{13} \mathrm{MrNV}$ and $2.23 \times 10^{12} \mathrm{XSV}$ $\mathrm{ml}^{-1}$ (i.e. $M r \mathrm{NV}: \mathrm{XSV}=8: 1$ ); Group 3: $4.20 \times 10^{9} \mathrm{MrNV}$ and $3.48 \times 10^{12} \mathrm{XSV} \mathrm{ml}^{-1}$ (i.e. $\mathrm{MrNV}: \mathrm{XSV}=1: 830$ ). $\mathrm{A}$ control group was treated with PBS only. The PL (81 for each group) were immersed in a virus suspension or PBS solution for 15 min and then transferred to freshwater tanks. The leftover virus suspensions were mixed with the powdered eggs used to feed the PL over the following $3 \mathrm{~d}$. Clinical signs were monitored daily. PL exhibiting white muscle were recorded and transferred to a separate tank. Seven PL were sampled from each group on Day 8 post-immersion (p.i.), and the remainder were harvested on Day 24 p.i. for storage at $-70^{\circ} \mathrm{C}$.

RNA extraction. Total RNA was extracted from whole PL with TRIzol reagent (Invitrogen) according to the manufacturer's protocol. The final RNA was resuspended in 40 to $50 \mu \mathrm{l} \mathrm{DEPC}$ water and stored at $-70^{\circ} \mathrm{C}$. For RNA extraction from viral particles, virus suspensions were digested with $200 \mu \mathrm{g} \mathrm{ml}^{-1}$ Proteinase $\mathrm{K}$ in $10 \mathrm{mM}$ Tris- $\mathrm{HCl}, 10 \mathrm{mM}$ EDTA (pH 8.0) and 0.5\% SDS at $37^{\circ} \mathrm{C}$ for $1 \mathrm{~h}$. RNA was extracted successively with phenol, phenol/chloroform/isoamyl alcohol (25:24:1, $\mathrm{v} / \mathrm{v} / \mathrm{v})$ and chloroform/isoamyl alcohol $(24: 1, \mathrm{v} / \mathrm{v})$, and then precipitated with $2.5 \mathrm{vol}$ of absolute ethanol after addition of $0.3 \mathrm{M}$ sodium acetate (final concentration) at $-20^{\circ} \mathrm{C}$ for $2 \mathrm{~h}$, followed by washing with $75 \%$ ethanol and dissolving as above.

Primers and probes. The primers and probes (Table 1) for MrNV and XSV detection were designed using Primer Express software (Version 2.0, Applied Biosystems) and targeted the MrNV RNA1 and XSV sequences, respectively (GenBank Nos. AY231436 and DQ174318). Taqman probes were labeled with the fluorescent reporter dye 6-carboxy-fluorescein (FAM) and the quencher 6-carboxy- $N, N, N, N$-tetra-methylrhodamine (TAMARA) at the $5^{\prime}$ - and 3 '-ends, respectively. The primers for 18S rRNA were designed from Macrobrachium rosenbergii 18S rRNA (AY461599). The amplicon sizes for MrNV RNA1, XSV and 18S rRNA were 75, 69 and $213 \mathrm{bp}$, respectively.

Preparation of quantitative standards. The amplicons of $M r N V$ RNA1 and XSV were cloned into pGEM-T easy vector (Promega). The plasmid DNA was extracted with a plasmid miniprep kit (Omega Bio-Tek). The amplicon of $18 \mathrm{~S}$ rRNA by RT-PCR was purified using an EZNA gel extraction kit (Omega BioTek). Copy numbers were calculated according to DNA concentrations using a Lambda 25 UV/VIS spectrometer (Perkin-Elmer). The DNA stocking solutions were aliquoted and stored at $-20^{\circ} \mathrm{C}$. One aliquot was serially diluted 10 -fold and used in real-time PCR with 
Table 1. Primers (FP: forward; RP: reverse) and probes used in real-time RT-PCR (MrNV: Macrobrachium rosenbergii nodavirus; XSV: extra small virus). Tm: annealing temperature

\begin{tabular}{|lllcc|}
\hline \multirow{2}{*}{ Target gene } & Primer and probe & Sequence $\left(5^{\prime} \rightarrow 3^{\prime}\right)$ & Tm & Amplicon $(\mathrm{bp})$ \\
\hline MrNV RNA1 & FP & CAACTCGGTATGGAACTCAAGGT & 58 & 75 \\
& RP & AGGAAATACACGAGCAAGAAAAGTC & 58 & 69 \\
XSV & Probe & ACCCTTCGACCCCAGCAATGGTG & 58 & 58 \\
& FP & AGCCACACTCTCGCATCTGA & 68 & 57 \\
18 S rRNA & RP & CTCCAGCAAAGTCGATACG & 57 & 213 \\
& Probe & CATGCCCCATGATCCTCGCA & 57 \\
\hline
\end{tabular}

either a Taqman probe ( $M r N V$ RNA1 and XSV) or SYBR Green I dye (18S rRNA).

Two-step real-time RT-PCR. Reverse transcription was performed in a $10 \mu \mathrm{l}$ volume. An aliquot of $3 \mu \mathrm{l}$ RNA with 10 pmol reverse primer and $2.8 \mu$ of diethylpyrocarbonate-treated $\mathrm{H}_{2} \mathrm{O}$ were first denatured at $70^{\circ} \mathrm{C}$ for $10 \mathrm{~min}$, then immediately quenched on ice and subsequently added to the RT mixture consisting of $0.6 \mathrm{mM}$ each of the 4-deoxynucleoside triphosphates, $8 \mathrm{U}$ RNasin (BioStar) and $80 \mathrm{U}$ M-MLV reverse transcriptase (Promega). The reverse transcription reaction was conducted at $42^{\circ} \mathrm{C}$ for $60 \mathrm{~min}$, followed by heating to $70^{\circ} \mathrm{C}$ for $5 \mathrm{~min}$ and holding at $4^{\circ} \mathrm{C}$.

Real-time PCR assays for $M r N V$ and XSV with Taqman probes were conducted in a DNAEngine OPTICON machine (MJ). The final PCR mixture $(25 \mu \mathrm{l})$ contained $0.4 \mu \mathrm{M}$ each of forward and reverse primers, $80 \mathrm{nM}$ Taqman probe, $0.5 \mathrm{U}$ of Taq polymerase (BioStar) and $5 \mu \mathrm{l}$ cDNA. The thermal cycling condi-

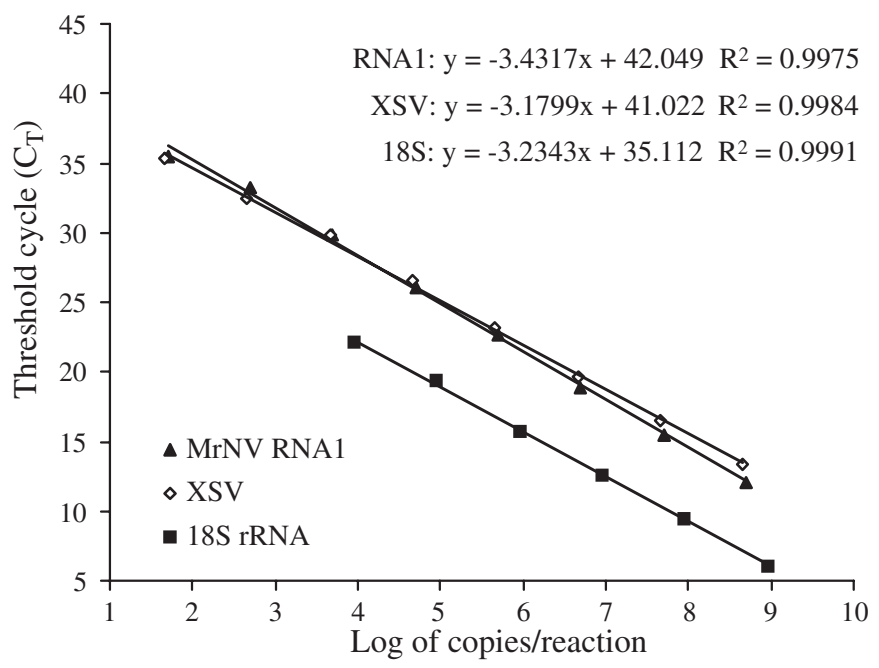

Fig. 1. Standard curves for MrNV RNA1, XSV and 18S rRNA real-time PCR assays tions were: $94^{\circ} \mathrm{C}$ for $5 \mathrm{~min}$, then 50 cycles of $94^{\circ} \mathrm{C}$ for $30 \mathrm{~s}$ and $58^{\circ} \mathrm{C}$ for $30 \mathrm{~s}$. Fluorescence was measured after each cycle. In the real-time PCR assay with SYBR Green I dye (OPE Tech) to quantify $18 \mathrm{~S}$ rRNA, the amplification profile was $94^{\circ} \mathrm{C}$ for $5 \mathrm{~min}$, followed by 40 cycles of $94^{\circ} \mathrm{C}$ for $30 \mathrm{~s}, 57^{\circ} \mathrm{C}$ for $30 \mathrm{~s}, 72^{\circ} \mathrm{C}$ for $30 \mathrm{~s}$ and $84^{\circ} \mathrm{C}$ for $5 \mathrm{~s}$ for plate reading to collect fluorescence data. A melting curve from 16 to $94^{\circ} \mathrm{C}$ was generated after the last extension step at $72^{\circ} \mathrm{C}$ for $10 \mathrm{~min}$.

Statistical analysis. The coefficient of variation of the real-time RT-PCR assays and standard error of the mean were calculated using Microsoft Excel 2000 and SPSS Version 10.0, respectively. Significant differences were determined using an independent-samples $t$-test, and correlation analysis was carried out using a bivariate correlation test with SPSS software.

\section{RESULTS}

\section{Sensitivity and reproducibility of real-time PCR assays}

To assess the dynamic range of the real-time PCR assays, DNA plasmids, or amplicons, fragments were serially diluted 10 -fold and tested 3 times in triplicate. Standard curves were constructed by plotting the logarithm of copy number against measured $C_{\mathrm{T}}$ (threshold cycle) values (Fig. 1). The curves covered a linear range of 50 to $5.0 \times 10^{8}, 45.8$ to $4.58 \times 10^{8}$ and $9.11 \times 10^{3}$ to 9.11 $\times 10^{8}$ copies per reaction $(25 \mu \mathrm{l})$ for $\mathrm{MrNV}, \mathrm{XSV}$ and $18 \mathrm{~S}$ rRNA, respectively. The linear correlations $\left(\mathrm{R}^{2}\right)$ between the $C_{\mathrm{T}}$ and the $\log$ of the copy number were $0.997,0.998$ and 0.999 for the 3 curves, respectively.

Reproducibility of the methods was evaluated by intra- and inter-assay variation. Each point for the serial 10-fold dilutions represented triplicate samples for 3 independent runs. The results are summarized in Table 2. In fact, Taqman probe real-time PCR could detect $<10$ copies per reaction, but the coefficient of variation exceeded $5 \%$ (data not shown). 
Table 2. Evaluation of reproducibility of quantitative real-time PCR assays. $C_{\mathrm{T}}$ values were determined from 9 replicates; intraassay coefficients of variation (CV) were determined from 3 replicates of each dilution; inter-assay CVs were determined from 3 independent assays performed on different days (abbreviations for target genes, see Table 1)

\begin{tabular}{|c|c|c|c|c|c|c|c|c|c|c|c|}
\hline \multicolumn{3}{|c|}{ Copy number } & \multicolumn{3}{|c|}{ Mean $C_{\mathrm{T}}$ value } & \multicolumn{3}{|c|}{ Intra-assay CV (\%) } & \multicolumn{3}{|c|}{ Inter-assay CV (\%) } \\
\hline RNA1 & XSV & $18 \mathrm{~S}$ & RNA1 & XSV & $18 \mathrm{~S}$ & RNA1 & XSV & $18 \mathrm{~S}$ & RNA1 & XSV & $18 \mathrm{~S}$ \\
\hline 8.70 & 8.66 & 8.96 & 12.10 & 13.39 & 6.00 & 0.70 & 0.80 & 4.60 & 1.34 & 0.99 & 3.90 \\
\hline 7.70 & 7.66 & 7.96 & 15.48 & 16.54 & 9.49 & 2.06 & 2.56 & 3.88 & 3.07 & 2.22 & 3.27 \\
\hline 6.70 & 6.66 & 6.96 & 18.85 & 19.59 & 12.62 & 0.85 & 0.76 & 3.27 & 1.75 & 1.90 & 3.78 \\
\hline 5.70 & 5.66 & 5.96 & 22.67 & 23.18 & 15.76 & 0.39 & 2.56 & 1.70 & 1.74 & 3.16 & 3.05 \\
\hline 4.70 & 4.66 & 4.96 & 26.06 & 26.60 & 19.36 & 0.37 & 1.15 & 0.88 & 3.14 & 1.93 & 3.01 \\
\hline 3.70 & 3.66 & 3.96 & 29.89 & 29.86 & 22.09 & 1.05 & 0.34 & 1.33 & 3.67 & 2.59 & 3.55 \\
\hline 2.70 & 2.66 & & 33.21 & 32.40 & & 2.01 & 2.63 & & 3.70 & 1.66 & \\
\hline 1.70 & 1.66 & & 35.40 & 35.33 & & 2.55 & 2.23 & & 3.55 & 3.46 & \\
\hline
\end{tabular}

\section{$\operatorname{MrNV}, \mathrm{XSV}$ purification and quantification}

By sequential sucrose gradient and $\mathrm{CsCl}$ isopycnic centrifugation, electron microscopy revealed that MrNV and XSV from the WTD-infected PL were well separated (Fig. 2). However, quantification by Taqman real-time RT-PCR showed that the $M r N V$ fraction $\left(3.16 \times 10^{12}\right.$ copies $\left.\mu^{-1}\right)$ still contained $8.90 \times 10^{10}$ copies $\mathrm{\mu l}^{-1}$ of XSV (i.e. about 35 times more $M r N V$ than XSV), while the XSV fraction $\left(3.60 \times 10^{11}\right.$ copies $\left.\mu l^{-1}\right)$ contained $4.34 \times 10^{8}$ copies $\mu l^{-1}$ of $M r N V$ (1 single $M r N V$ particle for about 830 XSV particles).

\section{Experimental infection and gross signs of disease}

At Day 6 p.i., white spots were observed on the telson of PL in Groups 1 and 2, the groups that were given combined viral doses in which $\mathrm{MrNV}$ dominated. The spots then spread to the whole abdominal musculature. White-tail prawns showed decreased activity.
The cumulative percentages of white-tail prawns on Day 24 p.i. were $>60$ and $40 \%$, respectively, for Groups 1 and 2 (Fig. 3). By contrast, many fewer PL showing gross signs of WTD were seen in Group 3 containing PL given combined viral doses in which XSV dominated. Only 2 suspicious prawns whose abdominal muscles were slightly white and semi-transparent were observed on Day 11 p.i. In addition, the average weight of non-white-tail and white-tail prawns in Group 2 decreased by 8 and $22 \%$, respectively, compared with the control group at Day 24 p.i. (data not shown).

\section{Quantification and statistical analysis of $\mathrm{MrNV}$ and XSV}

Real-time RT-PCR quantification of $M r N V$ and XSV genomic copies in infected tissue (Fig. 4) revealed no significant difference for $\mathrm{MrNV}$ copies between Groups 1 and 2 on Days 8 and 24 p.i. ( $>$ > 0.05). How-
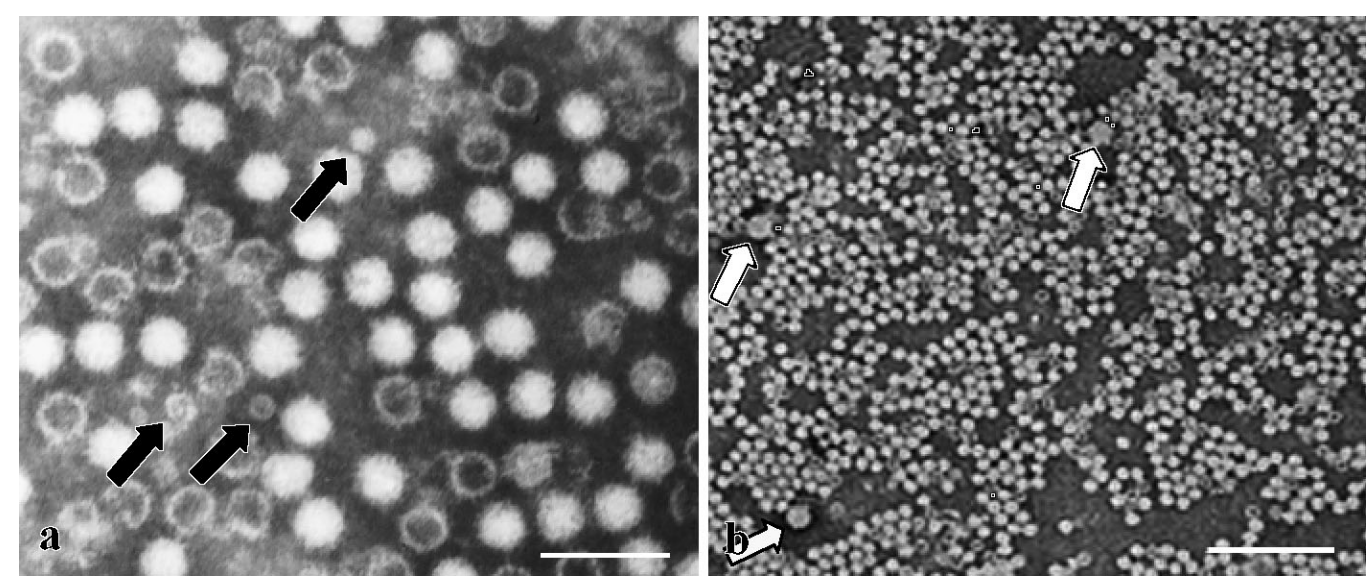

Fig. 2. Purified viral particles by transmission electron microscopy (TEM). There are some XSV (black arrows) remaining in the MrNV-containing fraction (a, scale bar: $200 \mathrm{~nm}$ ) and $M r N V$ (white arrows) remaining in the XSV-containing fraction (b, scale bar: $100 \mathrm{~nm}$ ) 


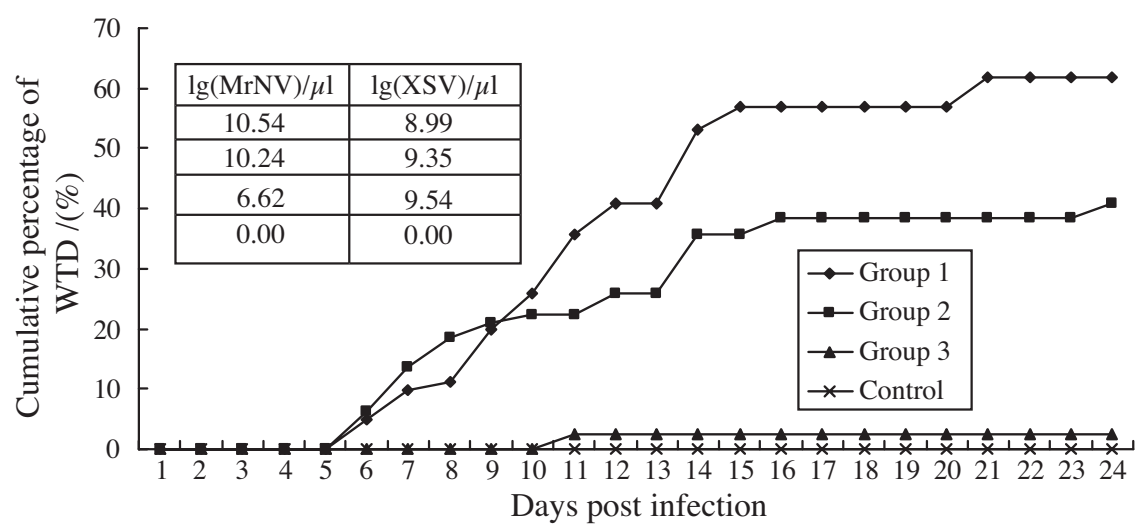

Fig. 3. Macrobrachium rosenbergii. Curve of cumulative count of post-larvae showing signs of white-tail disease (WTD) at various times during the postimmersion challenge. Virus inocula in the 3 groups are indicated in the table, while the control group was immersed in phosphate-buffered saline $(n=81)$

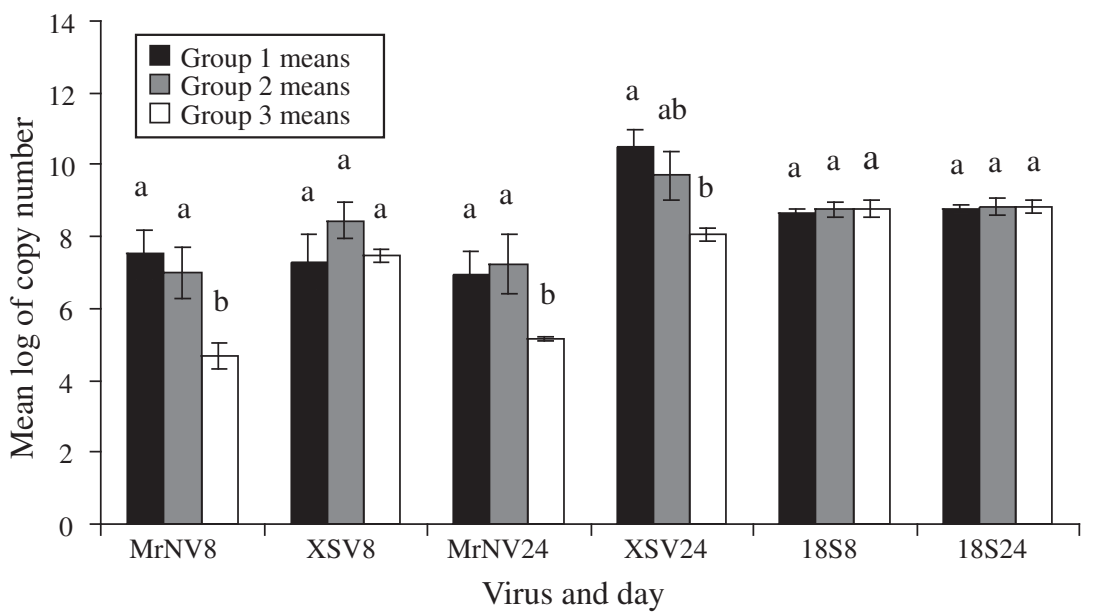

Fig. 4. Mean copy numbers of MrNV, XSV and $18 \mathrm{~S}$ rRNA at 8 and $24 \mathrm{~d}$ post-immersion challenge with $M r N V$ and XSV $(n=7)$. Bars in the same group with the same letters represent means that are not significantly different $(p>0.05)$ tively higher viral copies than those without white tails (data not shown). Therefore, on Day 24 p.i., PL in Group 2 that showed gross signs of WTD ( $\mathrm{n}=$ 19) were compared to those $(n=19)$ from the same group that did not (Fig. 5). It was found that the mean log of $\mathrm{MrNV}$ copies in non-white-tail prawns $\left(6.1 \times 10^{6}\right)$ was 10 times less than that in white-tail prawns $(6.1 \times$ $\left.10^{7}\right) \quad(p \quad<0.05)$. Accordingly, XSV genomic copies in non-white-tail prawns $\left(6.9 \times 10^{8}\right)$ and white-tail prawns $\left(9.7 \times 10^{9}\right)$ differed about 14 fold ( $p<0.05$ ). At the same time, the transcription of host 18S rRNA of the white-tail group $\left(3.5 \times 10^{9}\right)$ was also significantly higher than that of the non-white-tail group $\left(1.6 \times 10^{9}\right)(\mathrm{p}<$ $0.05)$, suggesting that viral replication could slightly interfere with transcription of host genes. This was in agreement with results from studies on panicum mosaic virus and its satellite virus infection in which there is a consistently sustained slight reduction of host rRNA expression (Scholthof 1999).

A scatter chart constructed by plotting the log of XSV genomic copies against the $\log$ of $\mathrm{MrNV}$ genomic copies, divided by the respective $18 \mathrm{~S}$ rRNA copies of each tested individual $(\mathrm{n}=80)$ (Fig. 6), resulted in a linear plot with a positive Pearson correlation coefficient of 0.729 calculated by SPSS software $(p<0.01)$. ever, MrNV copies in Group 3 were significantly lower than they were in Groups 1 and 2 ( $p<0.05$ ) on Days 8 and 24 p.i. This corresponded with the fact that Group 3 showed few gross signs of WTD. In the case of XSV, the copy numbers in 3 groups did not show significant differences on Day 8 p.i. ( $p>0.05$ ), while on Day 24 p.i., the copies in Group 1 were significantly higher than those in Group 3 ( $p<0.05)$. However, the overall XSV copy numbers were up to 2 logs or more higher than those of $\mathrm{MrNV}$ on both days. In the control group, a few samples gave $C_{\mathrm{T}}$ values above background and around 35. These values were distinctly higher than those from infected groups $\left(C_{\mathrm{T}}=15\right.$ to 26$)$ and were considered to result from non-specific amplification (data not shown).

When looking at MrNV and XSV copies of individual PL, it seemed that PL showing white tails had rela-

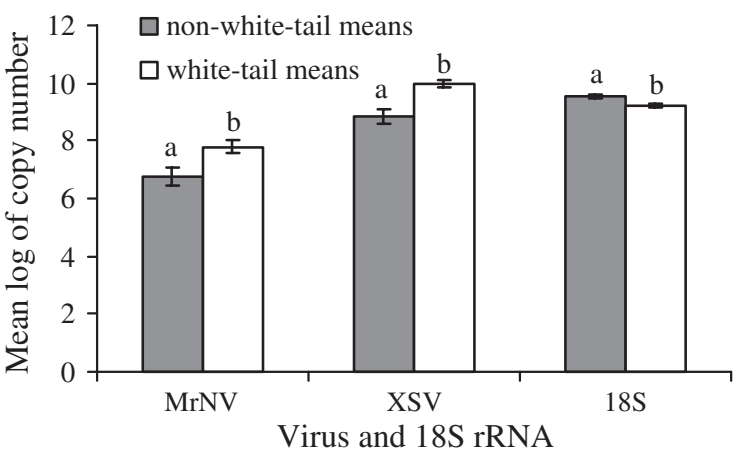

Fig. 5. Mean copy numbers of $M r N V, X S V$ and $18 \mathrm{~S}$ rRNA in shrimps with and without gross signs of white-tail disease $(\mathrm{n}=19)$. Bars in the same group with different letters are significantly different $(p<0.05)$ 


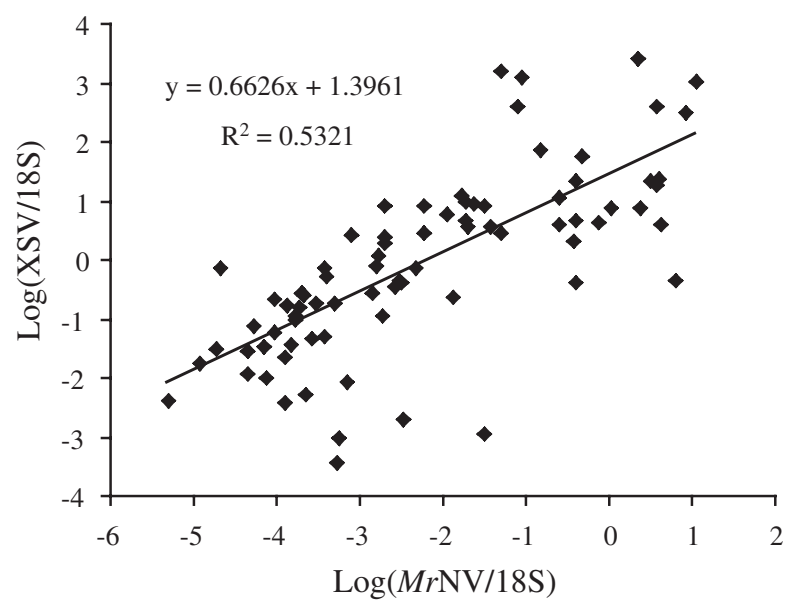

Fig. 6. Correlation between $M r N V$ and XSV copy numbers $(\mathrm{n}=80) ; x$ - and $y$-axes are the logarithms of $M r N V / 18 S$ rRNA and XSV/18S rRNA, respectively

\section{DISCUSSION}

The real-time RT-PCR we developed to quantify genomic copies of $\mathrm{MrNV}$ and XSV could detect $<10$ copies of virus per reaction $(25 \mu \mathrm{l})$ and was much more sensitive than conventional RT-PCR (Sri Widada et al. 2004). There was a strong linear relationship $\left(\mathrm{R}^{2}>\right.$ 0.99) over a wide dynamic range, from $10^{1}$ to $10^{8}$ copies per reaction. The quantification of host $18 \mathrm{~S}$ rRNA by real-time RT-PCR with SYBR Green I dye also gave a strong linear relationship, but with a relatively higher CV value $(>3 \%)$.

Our TEM results showed that MrNV and XSV could not be completely separated with sucrose and $\mathrm{CsCl}$ gradient centrifugation, so that it was not possible to use pure preparations of each virus in the challenge tests. Despite this limitation, we were able to show, by real-time RT-PCR, that genomic copies of both viruses were similar in Groups 1 and 2 and significantly higher than they were in Group 3. Comparing the infection dose of the 2 viruses in the 3 groups, we concluded that the higher the infection dose of $M r N V$, the higher the yield of both $M r N V$ and XSV. In addition, gross signs of WTD were seen with high MrNV numbers. This result was further supported by a strong positive linear correlation between these 2 viruses in infected prawns. These results support the contention that $M r N V$ plays a key role in WTD and that XSV is a satellite virus dependent on $\mathrm{MrNV}$.

Mean $M r N V$ and XSV genomic copies per nonwhite-tail prawns $\left(6.1 \times 10^{6}\right.$ and $6.9 \times 10^{8}$, respectively) and white-tail prawns $\left(6.1 \times 10^{7}\right.$ and $9.7 \times 10^{9}$, respectively) differed significantly $(p<0.05)$ by 10 or more times. Our comparison of viral copy numbers in nonwhite-tail prawns and white-tail prawns from Group 2 revealed that the non-white-tail prawns had subclini- cal infections despite the relatively high viral loads, especially for XSV. This result is in agreement with the work of Sahul Hameed et al. (2004). In their study, the 2 viruses failed to cause clinical signs or mortality when injected into adult prawns, although both were detected in many organs, except eyestalks and the hepatopancreas, by conventional RT-PCR. Such prawns showing no gross signs of disease could act as carriers of the virus and be responsible for virus transmission.

In most cases, the XSV copy numbers were much higher than those of $M r N V$, indicating an efficient replication of XSV. This large difference in viral loads of XSV and $\mathrm{MrNV}$ may lead to misinterpretation of conventional RT-PCR detection results. In a recent report, Yoganandhan et al. (2005) found that some prawns were $M r N V$ negative, but XSV positive by conventional RT-PCR. We detected $\mathrm{MrNV}$ in Group 1 prawns on Day 24 p.i. by a multiplex RT-PCR test established in our laboratory (authors' unpubl. data), but when genomic copies were $<10^{4}, M r N V$ could not be detected by conventional RT-PCR (data not shown).

To date, 4 plant satellite viruses, satellite tobacco necrosis virus (STNV), satellite maize white line mosaic virus (SMWLMV), satellite tobacco mosaic virus (STMV) and satellite panicum mosaic virus (SPMV) and an animal satellite virus (the chronic beeparalysis virus-associated satellite) have been recognized by the ICTV (www.ncbi.nlm.nih.gov/ICTVdb/ Ictv/fr-fst-g.htm). The function of some plant satellite viruses has been well analyzed by transgenetic techniques. The SPMV capsid protein acts as a pathogenicity factor in both host and non-host plants and interferes with suppression of gene silencing (Qiu \& Scholthof 2004). STNV was reported to suppress its helper virus replication and ameliorate the symptoms induced by the helper virus in different hosts (Jones \& Reichmann 1973, Kassanis 1981, Rodriguez-Alvarado et al. 1994). However, the presence of STMV did not modify (Valverde \& Dodds 1986, Valverde et al. 1991) or enhance the symptoms (Rodriguez-Alvarado et al. 1994) in different hosts. Although we have shown that MrNV is important in WTD outbreaks in prawns, the role of XSV in pathogenicity is still unclear and further work is needed to determine whether it plays any role.

Acknowledgements. This work was supported by the National Natural Science Foundation of China (Grant No. 30370057).

\section{LITERATURE CITED}

Anderson IG, Law AT, Shariff M, Nash G (1990) A parvo-like virus in the giant freshwater prawn, Macrobrachium rosenbergii. J Invertebr Pathol 55:447-449

Arcier JM, Herman F, Lightner DV, Redman RM, Mari J, Bonami JR (1999) A viral disease associated with mortalities in hatchery-reared postlarvae of the giant fresh- 
water prawn Macrobrachium rosenbergii. Dis Aquat Org 38:177-181

Bonami JR, Shi Z, Qian D, Sri Widada J (2005) White tail disease of the giant freshwater prawn, Macrobrachium rosenbergii: separation of the associated virions and characterization of $\mathrm{MrNV}$ as a new type of nodavirus. J Fish Dis 28:23-31

Jones IM, Reichmann ME (1973) The proteins synthesized in tobacco leaves infected with tobacco necrosis virus and satellite tobacco necrosis virus. Virology 52:49-56

Kassanis B (1981) Portraits of viruses: tobacco necrosis virus and its satellite virus. Intervirology 15:57-70

Nash G, Chinabut S, Limsuwan C (1987) Idopathic muscle necrosis in the freshwater prawn, Macrobrachium rosenbergii de Man, cultured in Thailand. J Fish Dis 10:109-120

Qian D, Yang G, Liu W, Wang J, Cao Z (2002) Preliminary studies on the whitish muscle diseases of Macrobrachium rosenbergii post-larvae. Acta Hydrobiol Sin 26:472-476

Qian D, Shi Z, Zhang S, Cao Z and 5 others (2003) Extra small virus-like particles (XSV) and nodavirus associated with whitish muscle disease in the giant freshwater prawn, Macrobrachium rosenbergii. J Fish Dis 26:521-527

Qiu W, Scholthof KB (2004) Satellite panicum mosaic virus capsid protein elicits symptoms on a nonhost plant and interferes with a suppressor of virus-induced gene silencing. Mol Plant-Microbe Interact 17:263-271

Rodriguez-Alvarado G, Kurath G, Dodds JA (1994) Symptom modification by satellite tabacco mosaic virus in pepper types and cultivars infected with helper tobamoviruses. Phytopathology 84:617-621

Romestand B, Bonami JR (2003) A sandwich enzyme-linked immunosorbent assay (S-ELISA) for dectection of $M r \mathrm{NV}$ in the giant freshwater prawn, Macrobrachium rosenbergii. J Fish Dis 26:71-75

Sahul Hameed AS, Yoganandhan K, Sri Widada J, Bonami JR (2004) Experimental transmission and tissue tropism of Macrobrachium rosenbergii nodavirus $(\mathrm{MrNV})$ and its associated extra small virus (XSV). Dis Aquat Org 62:191-196

Editorial responsibility: Timothy W. Flegel, Bangkok, Thailand
Scholthof KBG (1999) A synergism induced by satellite panicum mosaic virus. Mol Plant-Microbe Interact 12: 163-166

Shi Z, Qian D, Zhang J, Cao Z, Bonami JR (2004) Isolation, purification and nucleic acid characterization of two viral particles from freshwater prawn Macrobrachium rosenbergii. Chin J Virol 20:58-61

Sri Widada J, Bonami JR (2004) Characteristics of the monocistronic genome of extra small virus, a virus-like particle associated with Macrobrachium rosenbergii nodavirus: possible candidate for a new species of satellite virus. J Gen Virol 85:643-646

Sri Widada J, Durand S, Cambournac I, Qian D, Shi Z, Dejonghe E, Richard V, Bonami JR (2003) Genome-based detection methods of Macrobrachium rosenbergii nodavirus, a pathogen of the giant freshwater prawn, Macrobrachium rosenbergii, dot-blot, in situ hybridization and RT-PCR. J Fish Dis 26:583-590

Sri Widada J, Richard V, Shi Z, Qian D, Bonami JR (2004) Dotblot hybridization and RT-PCR detection of extra small virus (XSV) associated with white tail disease of prawn Macrobrachium rosenbergii. Dis Aquat Org 58:83-87

Tung CW, Wang CS, Chen SN (1999) Histological and electron microscopic study on Macrobrachium muscle virus (MMV) infection in the giant freshwater prawn, Macrobrachium rosenbergii (de Man), cultured in Taiwan. J Fish Dis 22:319-324

Valverde RA, Dodds JA (1986) Evidence for a satellite RNA associated naturally with the U5 strain and experimentally with the U1 strain of tobacco mosaic virus. J Gen Virol 67 : 1875-1884

Valverde RA, Heick JA, Dodds JA (1991) Interactions between satellite tobacco mosaic virus, helper tobamoviruses, and their hosts. Phytopathology 81:99-104

Yoganandhan K, Sri Widada J, Bonami JR, Sahul Hameed AS (2005) Simultaneous detection of Macrobrachium rosenbergii nodavirus and extra small virus by a single tube, one-step multiplex RT-PCR assay. J Fish Dis 28:65-69

Submitted: September 15, 2005; Accepted: February 22, 2006 Proofs received from author(s): June 19, 2006 